\title{
Minimalisasi Kekurangan Material melalui Implementasi Quality Control Circle
}

\author{
Togar W. S. Panjaitan ${ }^{1}$, Debora A. Y. A. ${ }^{1}$, Marissa Yessicha ${ }^{1}$
}

\begin{abstract}
The revolution of traditional quality management concept into total quality management (TQM) inspired industry for establishing and implementing quality control circle (QCC). Before starting a project as the implementation of the QCC, the training was held for supporting the knowledge of the QCC team. As the pilot project of the QCC, this research will try to minimize the percentage of the lack material in the production process of 8340 type by working together with the QCC team. The result of QCC implementation could reach the target set by the team, the percentage of the lack material reached less than $3 \%$. The percentage of the lack material kontaktarm reduced from $3.09 \%$ to $0.00 \%$, flachdrahtspule reduced from $9.20 \%$ to $0.40 \%$, and niet reduced from $7.71 \%$ to $2.73 \%$. Besides, the implementation of QCC also resulted in positive impact for all the members of the team about the benefits and experiences gained.
\end{abstract}

Keywords: Total quality management, quality control circle.

\section{Pendahuluan}

Perusahaan manufaktur yang menghasilkan komponen circuit breaker mengalami permasalahan khususnya di departemen fabrikasi dengan terjadinya kekurangan material pada saat produksi yang menyebabkan permintaan material tambahan Salah satu langkah yang diambil untuk mengatasi hal tersebut dengan meningkatkan sistem manajemen kualitas (Total Quality Management (TQM)) yang lebih baik. Keberadaan TQM adalah untuk memperkenalkan inti pokok dan philosofi utama yang lebih luas dari manajemen mutu, dimana Quality Control Circle (QCC) sebagai salah satu mekanisme pelaksanaannya (Asim [1D. Menurut Lee, untuk membentuk budaya kontrol kualitas secara total, organisasi harus menerapkan beberapa metode dasar kualitas kontrol dan perbaikan dalam berbagai aspek seperti fungsi organisasi dan sumber daya manusia. QCC adalah salah satu tools yang penting $(\mathrm{Hu}[5])$.

Quality Control Circle atau Gugus Kendali Mutu adalah ketepatan yang digunakan dan metode yang diterapkan untuk menghindari ketidaksempurnaan dalam layanan daripada verifikasi dan eliminasi. Oleh karena itu sikap karyawan mempengaruhi kualitas. Hal ini mendorong partisipasi karyawan serta mempromosikan kerja sama tim. Jadi memotivasi orang untuk berkontribusi terhadap efektivitas organisasi melalui proses kelompok (Gaikwad dan Gaikwad [3]).

1 Fakultas Teknonologi Industri, Jurusan Teknik Industri, Universitas Kristen Petra, Л Siwalankerto 121-131 Surabaya 60238. Email: togar@petra.ac.id

Diterima 18 Oktober 2011; revisi 15 November 2011; diterima untuk dipublikasikan 30 November 2011
Implementasi QCC untuk mengetahui bagaimana upaya yang dilakukan sehingga persentase kekurangan material selama proses produksi dapat diminimalkan.

\section{Metode Penelitian}

\section{Total Quality Management (TQM)}

Total Quality Manageme merupakan suatu strategi untuk mengimplementasikan dan mengelola aktivitas perbaikan kualitas pada sebuah organisasi. TQM meliputi konsep dan ide yang luas, melibatkan partisipasi dari seluruh anggota organisasi dan budaya kerja, fokus terhadap konsumen, perbaikan kualitas, integrasi sistem dengan tujuan yang ingin dicapai, dan aktivitas-aktivitas lain dalam suatu organisasi yang difokuskan pada tujuan perbaikan kualitas.

\section{Quality Control Circle (QCC)}

Quality Control Circle atau Gugus Kendali Mutu (GKM) merupakan suatu kelompok kecil yang terdiri dari beberapa orang yang bekerja secara bersama-sama sebagai pelopor dalam menjaga dan melakukan perbaikan secara terus-menerus terhadap kualitas produk, jasa, dan pekerjaannya (Nitta [9]). Menurut Summers, QCC bisa juga didefinisikan sebagai peningkatan kualitas atau perbaikan diri kelompok belajar terdiri dari sejumlah kecil karyawan, biasanya 10 atau kurang dan pengawas. Filosofi GKM telah diadaptasi dan dimodifikasi dari waktu ke waktu untuk memasukkan pemecahan masalah kegiatan tim. Para peserta, seringkali sukarela, menerima pelatihan dalam teknik pemecahan masalah, seperti cause-and-effect diagram dan control charts, menentukan masalah yang tepat 
untuk bekerja, mengembangkan solusi dan menetapkan prosedur baru untuk peningkatan kualitas (Liu et al. [7]). Menurut Robson [10], Gugus Kendali Mutu adalah sebuah kelompok yang terdiri dari 4 10 orang yang bergabung secara sukarela dan bekerja di bawah pengawasan seorang supervisor serta mengadakan pertemuan secara teratur untuk mengidentifikasi, menganalisis, dan memecahkan masalah.

\section{Penggunaan Metode Quality Control Story dan Plan-Do-Check-Act}

Problem Solving Quality Control (QC) Story adalah metode yang digunakan untuk melakukan pemecahan masalah dalam tim QCC serta mengorganisir informasi yang akan disajikan dalam laporan tentang hasil yang didapat dari upaya perbaikan kualitas atau kinerja (Katakura dan Toriumi[6]). Metode Plan-Do-Check-Act (P-D-C-A) merupakan sebuah model yang digunakan sebagai panduan untuk melakukan perbaikan. Metode QC Story dapat dipadukan penggunaannya dengan metode PD-C-A sebagai langkah-langkah dalam melakukan problem solving. Penerapan QCC dalam sebuah perusahaan memerlukan alat bantu dan teknik dalam melakukan pemecahan masalah. Secara umum, alat bantu yang digunakan pada penelitian ini meliputi Seven Tools for Quality Control dan Seven Management Tools for Quality Control. Seven Tools for Quality Control dan Seven Management Tools for Quality Control dapat saling melengkapi dalam menyelesaikan berbagai masalah kualitas secara efektif (Nayatani, et al. [8]).

\section{Hasil dan Pembahasan}

\section{Pembentukan QCC}

Pembentukan tim QCC merupakan salah satu program kerja dari Departemen Quality Control (QC) dan Change Management (CM). Peran serta tim QCC direalisasikan dalam aktivitas yang menunjang sistem manajemen kualitas, penyelesaian masalah di tempat kerja, dan memperbaiki kondisi lingkungan kerja yang meliputi sistem, permasalahan, dan kondisi dari semua departemen yang berpotensi untuk diperbaiki. Proses persiapan untuk aktivitas tim QCC ini dibuat dengan mengacu pada berbagai referensi dan pemikiran bersama, disesuaikan dengan kebutuhan di lapangan, dan ditetapkan melalui diskusi dan persetujuan Manajer Departemen QC dan CM sebagai penanggung jawab program.

\section{Pengembangan Aktivitas QCC}

Sebelum tim QCC memulai proyek, terlebih dahulu dilakukan pemberian materi atau training meliputi
Seven Tools for Quality Control dan Seven Management Tools for Quality Control dan dievaluasi dengan memberikan kesempatan terlibat langsung dalam proyek QCC yang dievaluasi pada akhir pilot project. Pada sebuah organisasi, pembagian tugas atau pekerjaan dapat dilakukan berdasarkan spesialisasi potensi yang dimiliki oleh masing-masing individu (Gibson, et al. [4]).

\section{Implementasi QCC}

Berikut ini adalah penjelasan mengenai proyek yang dilakukan oleh Tim Barakuda 1.

\section{Plan:}

Pemilihan Topik dan Alasannya

Penentuan topik masalah ditetapkan melalui diskusi dan menghasilkan tiga alternatif permasalahan yang akan dibahas yang dilanjutkan menentukan permasalahan yang akan dibahas terlebih dahulu sebagai pilot project. Proses pemilihan topik permasalahan dilakukan dengan prioritization matrices dan Nominal Group Technique (NGT). Penggunaan prioritization matrices (Tabel 1) cocok diimplementasikan untuk pengambilan keputusan yang bersifat verbal dan tidak didukung dengan tersedianya data yang bersifat numerik. Penentuan kriteria melalui kesepakatan seluruh anggota, yaitu kemudahan implementasi, kecepatan mencapai hasil, dan biaya. Selanjutnya tiap anggota memberikan bobot terhadap setiap kriteria. Nilai atau bobot paling kecil diberikan pada faktor yang kurang penting dan nilai atau bobot paling besar diberikan pada faktor yang paling penting. Permasalahan yang memiliki nilai tertinggi akan menjadi proyek yang dipilih (Besterfield[2]). Total bobot yang diberikan oleh masing-masing anggota harus bernilai 1 dan bobot yang diberikan dirata-rata untuk mendapatkan bobot tiap kriteria. Langkah selanjutnya adalah memberikan peringkat terhadap permasalahan yang ada berdasarkan hubungannya dengan tiap kriteria.

\section{Persiapan Rencana yang Akan Dilakukan}

Tim QCC merencanakan kegiatan yang akan dilakukan dan alokasi waktu untuk menyelesaikan proyek. Penelitian dimulai bulan Desember 2010 sampai bulan Mei 2011. Perencanaan implementasi proyek dilakukan dengan bantuan formulir rencana implementasi kegiatan tim QCC. Tujuan dari pembuatan rencana kegiatan supaya tim dapat melakukan kegiatan problem solving secara sistematis dengan mengikuti tahapan metode P-D-C-A dan QC Story pada jangka waktu yang diestimasikan. 
Tabel 1. Hasil prioritization matrices

\begin{tabular}{|c|c|c|c|c|c|c|}
\hline \multirow[b]{2}{*}{ Permasalahan } & \multicolumn{3}{|c|}{ Kriteria } & \multirow[b]{2}{*}{ 胥 } & \multirow[b]{2}{*}{ 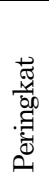 } & \multirow[b]{2}{*}{ Keterangan } \\
\hline & 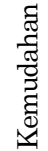 & 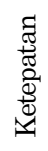 & 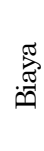 & & & \\
\hline
\end{tabular}

\begin{tabular}{|c|c|c|}
\hline $\begin{array}{l}\text { Hasil mesin } \\
\text { injeksi plastic } \\
\text { tidak stabil- } \\
\text { sering menga- } \\
\text { lami perbeda- } \\
\text { an warna } \\
\text { tekstur, dsb }\end{array}$ & $1 x 0,351 x 0,31$ 1x0,34 1,00 & $\begin{array}{l}3 \text { Proyek paling sulit } \\
\text { diimplementasikan, } \\
\text { memerlukan waktu } \\
\text { penyelesaian lama } \\
\text { dan biaya yang di- } \\
\text { perlukan paling } \\
\text { banyak }\end{array}$ \\
\hline $\begin{array}{l}\text { Kekurangan } \\
\text { material yang } \\
\text { diperlukan } \\
\text { pada proses } \\
\text { produksi } 8340\end{array}$ & $3 \times 0,352 \times 0,313 \times 0,342,70$ & $\begin{array}{l}1 \text { Proyek paling mu- } \\
\text { dah untuk dimple- } \\
\text { mentasikan, memer- } \\
\text { lukan waktu penye- } \\
\text { lesaian tidak terlalu } \\
\text { lama dan biaya } \\
\text { yang diperlukan } \\
\text { sedikit }\end{array}$ \\
\hline $\begin{array}{l}\text { Material } \\
\text { tercampur } \\
\text { selama proses } \\
\text { produksi (mi- } \\
\text { salnya bimetal } \\
\text { dengan } \\
\text { ampere yang } \\
\text { berbeda) } \\
\end{array}$ & $2 \times 0,353 \times 0,312 \times 0,342,30$ & $\begin{array}{l}1 \text { Proyek cukup mu- } \\
\text { dah untuk dimple- } \\
\text { mentasikan, memer- } \\
\text { lukan waktu } \\
\text { penyelesaian paling } \\
\text { cepat dan biaya } \\
\text { yang diperlukan } \\
\text { cukup banyak }\end{array}$ \\
\hline
\end{tabular}

\section{Pemahaman Mengenai Kondisi Saat Ini}

Langkah ini dilakukan melalui pengumpulan data awal dari dokumen perusahaan yang berisi informasi mengenai jenis dan jumlah material yang mengalami kekurangan selama proses produksi. Hasil persentase material yang mengalami kekurangan sebesar 3,91\% untuk setiap kejadian sedangkan nilai toleransi keakuratan hasil penimbangan (berdasarkan kesepakatan pihak gudang dengan supplier) sebesar 3\%. Tim Barakuda 1 memfokuskan pilot project ini pada beberapa jenis material tertentu saja yang menyebabkan dampak kerugian yang paling besar dengan mempertimbangkan dua hal, yaitu: (1) Jumlah material yang mengalami kekurangan dan biaya per satuan material yang digunakan dan (2) Waktu yang hilang akibat adanya proses pengisian formulir permintaan material.

Setiap kali terjadi kekurangan jumlah material selama proses produksi, terjadi penghentian proses produksi saat operator mengisi formulir permintaan material tambahan. Waktu rata-rata yang terbuang untuk penulisan formulir permintaan material tambahan adalah selama 3,74 menit.

\section{Penentuan Target dan Tujuan}

Jenis material yang menimbulkan dampak kerugian yang paling besar ditentukan berdasarkan prinsip pareto 80:20. Material yang menduduki lima peringkat teratas yang termasuk dalam $80 \%$, yaitu kontakarm, flachdrahtspule, bew.spule, verzogerungseinheit, dan niet (Gambar 1)

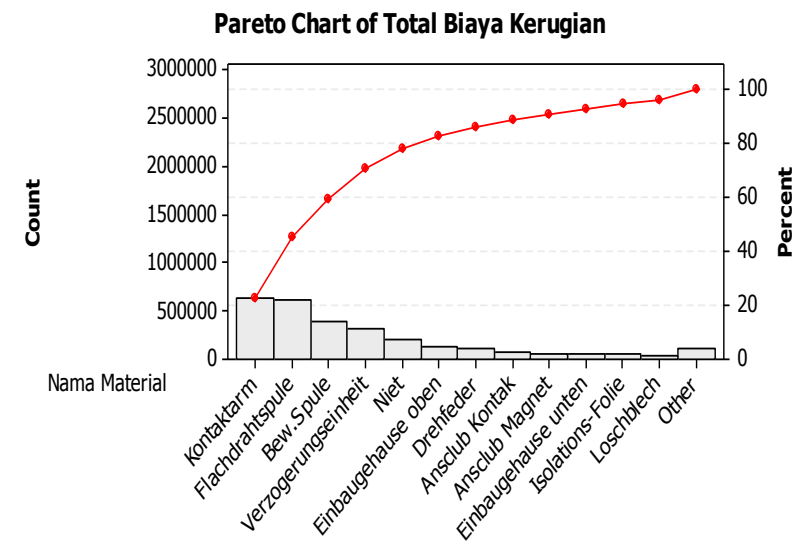

Gambar 1. Pareto diagram dari biaya kerugian akibat kekurangan material

\begin{tabular}{|c|c|c|c|c|}
\hline \multicolumn{2}{|c|}{ Kesalahan Penimbangan } & \multicolumn{3}{|c|}{ Material Hilang Saat Proses Produksi } \\
\hline $\begin{array}{c}\text { Timbangan belum } \\
\text { dikalibrasi } \\
\text { sehingga tidak } \\
\text { akurat }\end{array}$ & $\begin{array}{c}\text { Jumlah yang } \\
\text { tertera di } \\
\text { timbangan tidak } \\
\text { sesuai dengan } \\
\text { jumlah unit } \\
\text { sebenarnya } \\
\end{array}$ & $\begin{array}{c}\text { Material yang reject } \\
\text { langsung dibuang } \\
\text { dan dianggap } \\
\text { sebagai misscount }\end{array}$ & $\begin{array}{c}\text { Material tidak } \\
\text { ditaruh pada wadah } \\
\text { sehingga rawan } \\
\text { terjatuh ke lantai }\end{array}$ & \begin{tabular}{|c|} 
Material terjatuh ke \\
lantai dan tidak \\
diambil oleh operator, \\
kemudian hilang \\
karena tersapu \\
\end{tabular} \\
\hline \multirow{2}{*}{$\begin{array}{l}\text { Timbangan sering } \\
\text { error sehingga } \\
\text { hasil timbangan } \\
\text { kurang stabil }\end{array}$} & \multirow{2}{*}{$\begin{array}{c}\text { Tidak memenuhi } \\
\text { nilai toleransi hasil } \\
\text { timbangan yang } \\
\text { ditetapkan antara } \\
\text { pihak gudang dan } \\
\text { supplier } \\
\end{array}$} & \begin{tabular}{|c|} 
Material jatuh pada \\
saat dikeluarkan \\
dari kemasan \\
plastik
\end{tabular} & $\begin{array}{c}\text { Material tercampur } \\
\text { dengan jenis } \\
\text { material yang lain }\end{array}$ & \multirow{3}{*}{$\begin{array}{l}\text { Material yang masih } \\
\text { terselip tertinggal di } \\
\text { meja/terselip di } \\
\text { mesin tidak diketahui } \\
\text { oleh operator } \\
\text { kemudian dilakukan } \\
\text { pembersihan dengan } \\
\text { semprotran angin } \\
\text { sehingga material } \\
\text { tersebut terjatuh }\end{array}$} \\
\hline & & $\begin{array}{c}\text { Material tercampur } \\
\text { dengan nomer } \\
\text { interen yang lain }\end{array}$ & \multirow{2}{*}{\begin{tabular}{|c|} 
Material terselip/ \\
tertinggal di mesin/ \\
di meja dan tidak \\
diketahui oleh \\
operator sehingga \\
jumlah yang \\
disediakan kurang
\end{tabular}} & \\
\hline & & & & \\
\hline
\end{tabular}

Gambar 2. Diagram affinity

Peninjauan ulang terhadap persentase kekurangan jumlah material perlu dilakukan lagi terhadap kelima material yang telah ditetapkan sebagai penyebab kerugian yang terbesar berdasarkan pareto diagram. Hal tersebut dikarenakan adanya nilai toleransi timbangan sebesar 3\% dan tidak semuanya melebihi batas toleransi timbangan sebesar 3\%. Material yang mengalami persentase kekurangan lebih dari $3 \%$, yaitu kontaktarm, flachdrahtspule, dan niet.

\section{Do}

\section{Pencarian Penyebab Permasalahan}

Tahap selanjutnya yang dilakukan oleh tim adalah mencari penyebab terjadinya kekurangan material selama proses produksi. Sebelum melakukan analisis untuk menemukan akar penyebab kekurangan material selama proses produksi, tim terlebih dahulu melakukan pengumpulan ide dengan bantuan affinity diagram pada Gambar 2. Fishbone diagram untuk mencari akar masalah karena kesalahan penimbangan dapat dilihat pada Gambar 3, dan fishbone diagram hasil diskusi untuk mencari akar permasalahan dari material yang hilang selama proses produksi dapat dilihat pada Gambar 4. 


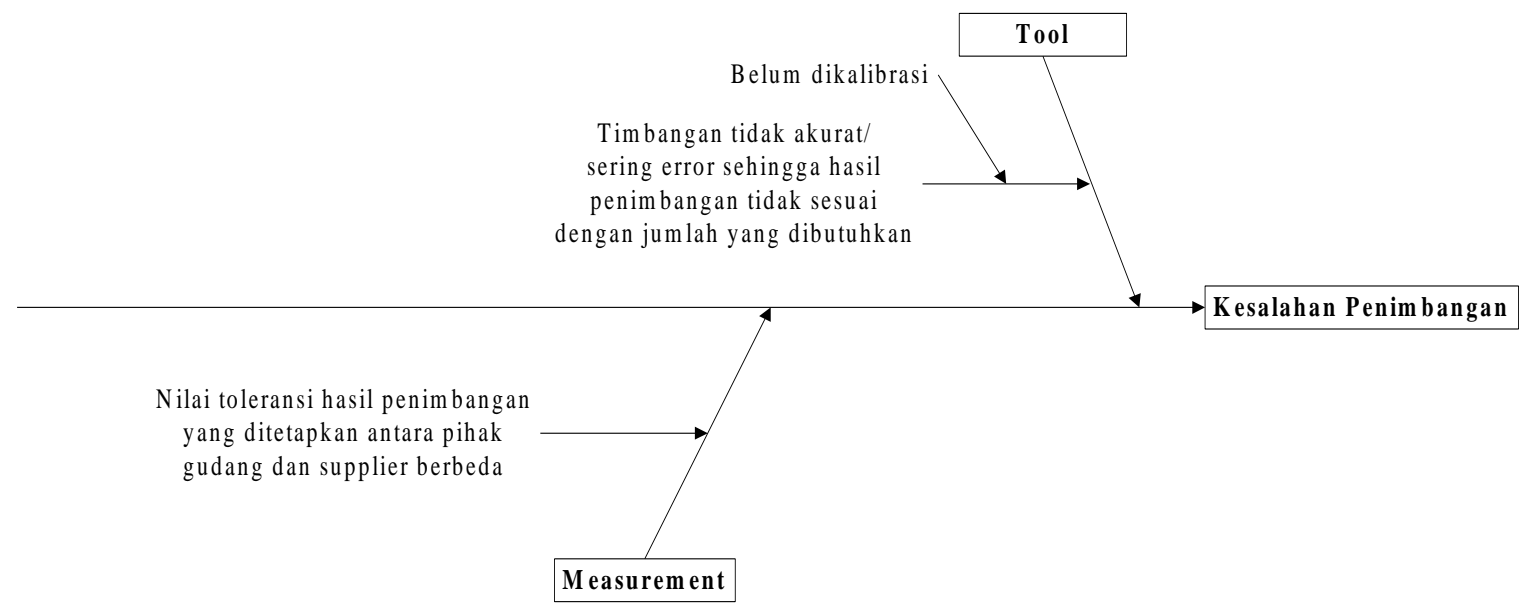

Gambar 3. Diagram Fishbone: Kesalahan penimbangan

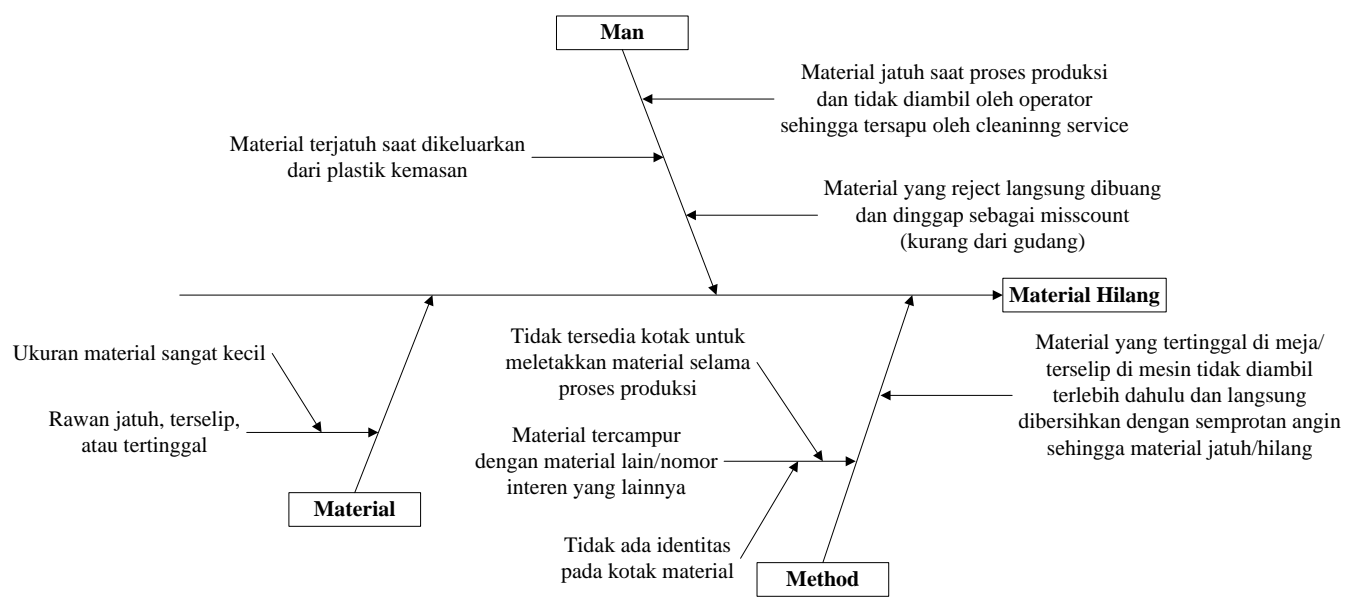

Gambar 4. Diagram Fishbone: Material hilang

Perancangan dan Penerapan Solusi Perbaikan

Tim Barakuda 1 menentukan solusi potensial yang dapat dilakukan untuk memperbaiki setiap akar masalah. Perancangan solusi perbaikan yang akan dilakukan dapat dilihat pada Tabel 2.

Berikut ini adalah penjelasan dari solusi-solusi yang diimplementasikan selama periode penelitian dan disesuaikan dengan urutan implementasinya selama penelitian dilakukan.

Mengadakan inspeksi mendadak awal ke lantai produksi tipe 8340. Inspeksi mendadak awal dilakukan untuk mengetahui kondisi lingkungan kerja dan perilaku operator yang berpotensi menyebabkan hilangnya material selama proses produksi dan terdapat beberapa temuan yang berpotensi menyebabkan hilangnya material seperti material terjatuh di lantai, tercecer di meja kerja, terselip di mesin, terbuang ke tempat sampah, operator kurang berhati-hati atau teliti dalam menempatkan material, dan lain-lain.
Tabel 2. Perancangan dan penerapan solusi perbaikan

\begin{tabular}{|c|c|c|}
\hline Permasalahan & Akar permasalahan & Solusi perbaikan \\
\hline \multirow[b]{2}{*}{$\begin{array}{l}\text { Kesalahan } \\
\text { Penimbangan }\end{array}$} & $\begin{array}{l}\text { Timbangan belum dikali- } \\
\text { brasi sehingga tidak akurat }\end{array}$ & $\begin{array}{l}\text { Kalibrasi } \\
\text { timbangan }\end{array}$ \\
\hline & $\begin{array}{l}\text { Nilai toleransi hasil } \\
\text { penimbangan belum tentu } \\
\text { sesuai dengan ketetapan } \\
\text { sebesar } 3 \%\end{array}$ & $\begin{array}{l}\text { Sampling untuk } \\
\text { menguji } \\
\text { keakuratan }\end{array}$ \\
\hline \multirow{5}{*}{$\begin{array}{l}\text { Material } \\
\text { hilang selama } \\
\text { proses } \\
\text { produksi }\end{array}$} & $\begin{array}{l}\text { Material jatuh dan dibiar- } \\
\text { kan saja. } \\
\text { Material jatuh saat dike- } \\
\text { luarkan dari plastik } \\
\text { kemasan }\end{array}$ & $\begin{array}{l}\text { Sosialisai } \\
\text { kehatian-hatian } \\
\text { dalam bekerja }\end{array}$ \\
\hline & $\begin{array}{l}\text { Material yang dinyatakan } \\
\text { cacat langsung dibuang. }\end{array}$ & Identifikasi \\
\hline & $\begin{array}{l}\text { Tidak tersedia kotak untuk } \\
\text { meletakkan material } \\
\text { selama proses produksi } \\
\text { Tidak ada identifikasi pada } \\
\text { kotak material. }\end{array}$ & $\begin{array}{l}\text { Penyediaan } \\
\text { kotak dengan } \\
\text { identitas untuk } \\
\text { tiap material }\end{array}$ \\
\hline & $\begin{array}{l}\text { Material tertinggal/terselip } \\
\text { di mesin/meja kerja dan } \\
\text { hilang saat dilakukan } \\
\text { pembersihan. }\end{array}$ & $\begin{array}{l}\text { Himbauan untuk } \\
\text { meneliti meja } \\
\text { kerja sebelum } \\
\text { dibersihkan }\end{array}$ \\
\hline & $\begin{array}{l}\text { Material berukuran sangat } \\
\text { kecil }\end{array}$ & \\
\hline
\end{tabular}


Melakukan sosialisasi. Berdasarkan hasil inspeksi mendadak, tim menyimpulkan bahwa potensi kehilangan material terjadi karena kondisi lokasi kerja yang tidak teratur dan perilaku kerja operator yang kurang tepat sehingga tim sepakat untuk menyusun materi sosialisasi mengenai penataan ulang lokasi kerja dan perilaku kerja yang benar.

Penyediaan tempat dan pemberian identitas material pada kotak yang digunakan dalam proses produksi. Penyediaan tempat untuk material dilakukan pada setiap proses dengan menyiapkan kotak material yang sesuai dengan kebutuhan agar dapat meminimalkan kehilangan material akibat material tercecer di meja, terselip di mesin, atau jatuh ke lantai. Setelah dilakukan penyediaan kotak, solusi selanjutnya yang diimplementasikan adalah pemberian identitas material pada kotak yang digunakan karena terdapat banyak jenis dan tipe material yang digunakan selama produksi tipe 8340 sehingga meminimalkan resiko tercampurnya material, dan membiasakan operator untuk mengenali material berdasarkan nama dan nomor artikel dari material tersebut sesuai dengan picking list.

Penegasan ulang untuk prosedur identifikasi material yang dinyatakan tidak lolos/penolakan (Reject). Operator wajib memberikan identifikasi yang benar untuk material yang mengalami penolakan bahan baku atau penolakan saat proses produksi dan meletakkan kotak kerusakan material yang disediakan. Selanjutnya, operator baru melakukan permintaan material tambahan dengan alasan terdapat material yang mengalami penolakan bahan baku atau penolakan proses.

Cara pembersihan meja kerja dan mesin dengan benar. Cara pembersihan meja kerja yang benar perlu disosialisasikan kepada operator untuk mengantisipasi hilangnya material (terutama untuk material yang berukuran sangat kecil) akibat pembersihan meja dan mesin dengan semprotan angin. Hasil temuan inspeksi mendadak menunjukkan bahwa terdapat banyak material yang tertinggal di meja dan terselip di mesin. Operator diwajibkan untuk memeriksa terlebih dahulu meja kerja dan mesin yang digunakan sebelum melakukan pembersihan dengan semprotan angin.

Memeriksa ulang hasil penimbangan material. Pemeriksaan ulang terhadap hasil penimbangan di gudang ini perlu dilakukan untuk mengetahui apakah ketentuan nilai toleransi yang ditetapkan berdasarkan kesepakatan pihak gudang dan supplier terhadap hasil penimbangan masih terpenuhi. Kontrol terhadap timbangan untuk memenuhi nilai toleransi dilakukan dengan kalibrasi timbangan secara teratur sesuai dengan jadwal yang ditetapkan oleh Departemen Quality Control.
Untuk memastikan keakuratan hasil timbangan dengan nilai toleransi $3 \%$, maka anggota tim melakukan pemeriksaan ulang terhadap hasil penimbangan dengan menghitung secara manual manual terhadap 15 sampel untuk masing-masing material. Hasil pengecekan ulang menunjukkan bahwa hasil penimbangan berada dalam batas toleransi. Dapat disimpulkan kekurangan jumlah material disebabkan karena hilangnya material selama proses produksi karena rata-rata persentase jumlah kehilangan material pada tiga jenis material yang menjadi fokus dalam pilot project masih berada di atas $3 \%$.

\section{Check}

Analisis perubahan yang terjadi sebelum dan sesudah perbaikan.

Setelah berbagai solusi diimplementasikan untuk meminimalkan jumlah kekurangan material selama proses produksi, maka tim mulai melakukan pemeriksaan terhadap hasil yang diperoleh dari pilot project ini. Hasil rekap kekurangan material dari ketiga material setelah dilakukan implementasi solusi oleh tim QCC dapat dilihat pada Tabel 3. Perbandingan hasil rekap jumlah material yang mengalami kekurangan dan persentase total material yang mengalami permintaan tambahan karena kekurangan material terhadap total picking list sebelum dan sesudah implementasi solusi perbaikan dapat dilihat pada Tabel 4 dan Gambar 5.

Tabel 3. Data persentase kekurangan material pada akhir penelitian

\begin{tabular}{lccc}
\hline Nama material & $\begin{array}{c}\text { Total permintaan } \\
\text { tambahan (PT) }\end{array}$ & $\begin{array}{c}\text { Total picking } \\
\text { list (PL) }\end{array}$ & $\begin{array}{c}\text { Persentase } \\
\text { PT/PL }\end{array}$ \\
\hline Kontaktarm & 0 & 0 & $0.00 \%$ \\
Flachdrahtspule & 4 & 1000 & $0,40 \%$ \\
Niet & 164 & 6016 & $2,73 \%$ \\
\hline
\end{tabular}

Tabel 4. Perbandingan persentase kekurangan material sebelum dan sesudah Perbaikan

\begin{tabular}{lcc}
\hline \multirow{2}{*}{ Nama material } & \multicolumn{2}{c}{ Persentase kekurangan material } \\
\cline { 2 - 3 } & Sebelum perbaikan & Sesudah perbaikan \\
\hline Kontaktarm & $3,09 \%$ & $0,00 \%$ \\
Flachdrahtspule & $9,20 \%$ & $0,40 \%$ \\
Niet & $7,71 \%$ & $2,73 \%$ \\
\hline
\end{tabular}

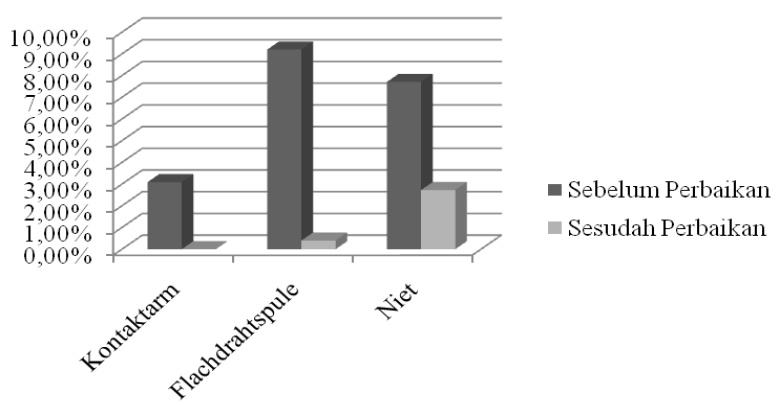

Gambar 5. Perbandingan persentase kekurangan material sebelum dan sesudah perbaikan 
Tabel 5. Hasil rekap evaluasi manfaat dan pengalaman anggota Tim Barakuda 1 setelah mengikuti QCC

\begin{tabular}{llcc}
\hline No & \multicolumn{1}{c}{$\begin{array}{c}\text { Pengalaman/manfaat yang } \\
\text { diperoleh }\end{array}$} & \multicolumn{2}{c}{ Jumlah Persentase } \\
\hline 1 & $\begin{array}{l}\text { Mengetahui cara yang sistematis } \\
\text { untuk mengatasi masalah dalam }\end{array}$ & 5 & $38,46 \%$ \\
pekerjaan berdasarkan data & & \\
2 & $\begin{array}{l}\text { Hasil proyek dapat diimplemen- } \\
\text { tasikan pada pekerjaan }\end{array}$ & 4 & $30,77 \%$ \\
3 & Belajar bekerja sama dalam tim & 2 & $15,38 \%$ \\
4 & $\begin{array}{l}\text { Mendapatkan pengetahuan baru } \\
\text { tentang terutama tentang QCC }\end{array}$ & 2 & $15,38 \%$ \\
\hline \multicolumn{1}{c}{ Total } & 13 & $100 \%$ \\
\hline
\end{tabular}

\section{Act}

Solusi perbaikan yang telah diimplementasikan perlu distandarkan agar kondisi perbaikan yang telah dicapai dapat terus dipertahankan. Hal-hal yang perlu dilakukan untuk menjaga hasil meliputi: (1) Penambahan prosedur kerja, yang terdiri dari penambahan prosedur pemberian identitas pada kotak sesuai dengan material yang diletakkan pada kotak tersebut dan prosedur pembersihan lokasi kerja dan mesin serta (2) Mengadakan inspeksi mendadak secara berkala ke lantai produksi tipe 8340 dimana waktunya secara berkala berdasarkan kesepakatan anggota tim QCC.

\section{Evaluasi Keberhasilan Implementasi QCC}

Keberhasilan pilot project QCC dari Tim Barakuda 1 ini dapat dievaluasi dari penurunan jumlah material yang mengalami kekurangan di proses produksi tipe 8340 dan pencapaian target serta tujuan sesuai dengan batasan waktu yang telah direncanakan. Solusi-solusi yang telah diimplementasikan dalam penelitian ini dapat mengurangi persentase kekurangan material selama proses produksi. Pada pilot project ini, evaluasi terhadap performa kerja tim secara kolektif dan anggota tim secara individu belum dapat dilaksanakan sebagai suatu bentuk kompetisi QCC di perusahaan. Sesuai dengan kesepakatan dengan Steering Committee dan Facilitator, tujuan utama yang ingin dicapai dalam pilot project ini bukanlah untuk menentukan penilaian terhadap tim maupun anggota yang terbaik, tetapi lebih difokuskan pada segi manfaat dan pengalaman yang diperoleh seluruh anggota tim QCC dengan adanya pembentukan QCC. Hasil rekap evaluasi manfaat dan pengalaman dari seluruh anggota Tim Barakuda 1 dapat dilihat pada Tabel 5.

\section{Simpulan}

Proyek QCC yang diimplementasikan oleh Tim Barakuda 1 berhasil meminimalkan persentase kekurangan material yang terjadi selama proses produksi circuit protection and control tipe 8340. Keberhasilan tersebut dapat dilihat dari penurunan persentase kekurangan tiga jenis material yang dijadikan target pada proyek ini. Persentase kekurangan material flachdrahtspule mengalami penurunan dari 9,20\% menjadi 0,40\%, kontaktarm mengalami penurunan dari 3,09\% menjadi $0 \%$, dan niet mengalami penurunan dari $7,71 \%$ menjadi $2,73 \%$, dan persentase kekurangan material masih berada di bawah $3 \%$. Hal tersebut berarti hasil penimbangan material akurat sesuai dengan nilai toleransi yang ditetapkan dan kehilangan selama proses produksi juga dapat diminimalkan. Upaya yang dilakukan untuk menjaga hasil penurunan persentase material agar tidak kembali ke kondisi semula adalah dengan melakukan penambahan prosedur kerja dan melakukan sidak secara berkala ke lantai produksi.

\section{Daftar Pustaka}

1. Asim, M., Adopting Quality Management Concepts in Public Service Reform, Labour and Management in Development Journal, 2(6), 2001, Asia Pasific Press.

2. Besterfield, D. H., Besterfield, C., Besterfield, G. H., and Besterfield, M., Total Quality Management, 3rd ed. New York: Pearson Education Inc, 2003.

3. Gaikwad, V. V., and Gaikwad, A. V., Quality Circle as an Effective Management Tool : A Case Study of Indira College of Engineering and Management Library, Proceeding of International Conference on Academic Libraries (ICAL2009), New Delhi, India

4. Gibson, J. L., Ivancevich, J. M., and Donnelly, J. H., Organizations: Behavior, Structure, Processes 10th ed. McGraw Hill, 2000.

5. Hu, T. C., Quality Improvement: Reducing Real - Time Inventory Errors through Quality Control Circles, African Journal of Business Management, 5(26), 2011, pp. 10657-10666.

6. Katakura, M., and Toriumi, K., The QC Problem Solving Approach: Text of QC methods, Paper presented at Program for Quality Management Promotion hold by The Association for Overseas Technical Scholarship, Japan, 2010.

7. Liu, S. C., Wu, H. H., and Chen, H. K., Improving Organizational Performance by a Quality Control Circle: A Case of Medication Improvement Team at a Hospital in Taiwan, Information Technology Journal, 9, 2010, pp. 692-697.

8. Nayatani, Y., Eiga, T., Futami, R., and Miyagawa, H., The Seven New QC Tools: Practical Applications for Managers, J. H. Loftus, Trans. Japan: JUSE Press Ltd, 2010.

9. Nitta, T., Basic for Promoting QC Circle Activities. Presented at Program for Quality Management Promotion Hold by the Association for Overseas Technical Scholarship, Japan, 2010.

10. Robson, M., Gugus Kendali Mutu, Alex Sindoro, Trans. Jakarta: Binarupa Aksara, 1993. 